\title{
TOTAL ANTHOCYANIN, FLAVONOID, POLYPHENOL AND TANNIN CONTENTS OF SEVEN POMEGRANATE CULTIVARS GROWN IN IRAN
}

\author{
Javad Mottaghipisheh ${ }^{1}$, Mehdi Ayanmanesh², Ramin Babadayei-Samani², \\ Alireza Javid ${ }^{2}$, Mina Sanaeifard ${ }^{3}$, Sara Vitalini ${ }^{4}$, Marcello Iriti ${ }^{4 \bowtie}$ \\ ${ }^{1}$ Department of Pharmacognosy, University of Szeged \\ Eötvös 6, H-6720, Szeged, Hungary \\ ${ }^{2}$ Department of Horticultural Science, Islamic Azad University Estahban Branch \\ No. 69, Niroo Av., Satarkhan Str., 14536-33143 Tehran, Iran \\ ${ }^{3}$ Department of Horticultural Science, Islamic Azad University Fars Province \\ Jahrom Branch, 85318 74147, Iran \\ ${ }^{4}$ Department of Agricultural and Environmental Sciences, Milan State University Fars Province \\ Giovanni Celoria 2, 20133 Milan, Italy
}

\begin{abstract}
Background. Pomegranates are healthy fruits rich in bioactive phytochemicals and widely consumed in the human diet. This study was designed to assess their physico-chemical properties and total polyphenolic compounds, along with antioxidant and ascorbic acid concentrations of the skin and juice of seven unstudied pomegranate cultivars grown in Iran.

Materials and methods. Ten fruits of each of seven selected cultivars were picked. Methanolic extracts from the fruit skins as well as juices were subjected to an evaluation of their physico-chemical properties and phenolic content.

Results. From the pomegranate cultivars studied, the highest juice concentration was measured in 'Zagh-e-Zabol' $(72.9 \pm 2.55 \%)$. The highest total soluble solids $\left(18.79 \pm 1.06^{\circ}\right.$ Brix $)$ of juice, as well as the highest ascorbic acid (16.54 $\pm 2.09 \mathrm{mg} / 100 \mathrm{~g})$ and total anthocyanin content of skin [11.20 $\pm 2.4 \mathrm{mg}$ CyE (cyanidin-3-glucoside equivalent)/L] were measured in 'Bajestan'. Total flavonoids were more concentrated in the skin of 'Siah-e-Zabol' [930 $\pm 16 \mathrm{mg}$ QuE (quercetin equivalent)/L]. In the juice of 'Rabab-e-Pust Ghermez' and 'Malas-e-Saveh' the highest concentrations of phenolic compounds were recorded [1082 $\pm 12.8 \mathrm{mg} \mathrm{GaE}$ (gallic acid equivalent)/L] and tannins $[6.55 \pm 0.5 \mathrm{mg} \mathrm{TaE}$ (tannic acid equivalent)/L], respectively.

Conclusion. Significant differences were assessed between the skin and juice of the cultivars in terms of their physico-chemical properties and polyphenolic contents. The results showed higher levels of total tannins, phenolics and antioxidant activity in juice of pomegranate, whereas the skins possessed higher total flavonoid, anthocyanin and ascorbic acid content. Further phytochemical analysis are therefore needed to identify the most representative phenylpropanoids by LC-MS (liquid chromatography coupled to mass spectrometry) and to develop novel and promising dietary supplements.
\end{abstract}

Keywords: Punica granatum L., functional foods, nutraceuticals, bioactive phytochemicals, antioxidant activity, ethnobotany

This study was financially supported by Islamic Azad University, Estahban Branch, Iran.

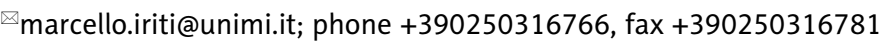




\section{INTRODUCTION}

The pomegranate (Punica granatum L., Lythraceae) is one of the oldest edible fruits. It is widely grown in some parts of Asia, North Africa, around the Mediterranean areas and in the Middle East (Sarkhosh et al., 2006). P. granatum has more than 500 cultivars (Stover and Mercure, 2007). The origins of the pomegranate can be found in central Asia, especially the Transcaucasia-Caspian region of Iran (Harlan, 1992), from which it spread to the rest of the world (Levin, 1994; Verma et al., 2010). As the centre of pomegranate growing, Iran possesses more than 800 genotypes, which have been collected and maintained in Yazd and Saveh germplasm (Behzadi Shahrbabaki, 1998). The pomegranate is renowned as the 'Paradise fruit' in Iranian culture. The seeds of pomegranate were considered to be an agent of resurrection by Babylonians; the Persians believed the seeds helped invincibility on the battlefields; in ancient China the seeds signified longevity and immortality (Aviram et al., 2000). The antioxidant activity of the pomegranate has been previously evaluated (Ambigaipalan et al., 2017; Mphahlele et al., 2016; Turgut et al., 2017). It is worth noting that the composition of pomegranate juice varies with several climatic and local conditions, in addition to the cultivating parameters (Melgarejo et al., 2000; Özkan, 2002).

Twenty (Tehranifar et al., 2010a), fifteen (Tehranifar et al., 2010b) and six (Zarei et al., 2010) different pomegranate cultivars grown in Iran were studied to evaluate their physico-chemical characteristics and antioxidant potential. Furthermore, these characteristics have been previously reported from various cultivars in some regions around the world (Hmid et al., 2017; Hmid et al., 2016; Li et al., 2015; Ozgen et al., 2008; Zaouay et al., 2012).

This study aimed at evaluating the physico-chemical properties, total phenolic, tannin, anthocyanin and flavonoid contents, antioxidant activity and ascorbic acid concentration of the skin and juice of seven selected and not yet investigated pomegranate cultivars grown in Iran.

\section{MATERIALS AND METHODS}

\section{Sample collection and preparation of the skin extract and juice}

The selected pomegranate cultivars were harvested in Iran: 'Rabab-e-Pust Sefid' (RPS) and 'Rabab-e-Pust Ghermez' (RPGH) from Neyriz, 'Zagh-e-Zabol' (ZZ) and 'Siah-e-Zabol' (SZ) from Zabol, 'Malas-e-Yazd' (MY) from Yazd, 'Malas-e-Saveh' (MS) and 'Bajestan' (B) from Saveh. Ten fruits of each cultivar were picked on the same day (15th September 2014) from 10 trees in each orchard. The pomegranate fruits were packed and kept at a temperature of $4^{\circ} \mathrm{C}$ and relative humidity of $85 \%$ in plastic bags and shock-proof cartons. Methanolic extracts of the fruit skins (peels) were obtained by the maceration method. Ten $\mathrm{mL}$ of $\mathrm{MeOH}$ were added three times to $500 \mathrm{mg}$ dried pomegranate skins, separately for each cultivar. After filtering and evaporating the solvent, methanolic extracts were yielded and prepared for further analysis.

The pomegranate juices were individually obtained by mechanically squeezing their fruit seeds.

\section{Physical characteristics}

Ten fruits of each cultivars were weighed in the air on scales with an accuracy of $0.001 \mathrm{~g}$ (sartorius, TE-412). The density of the fruit was obtained by the ratio of weight to volume. The juice and skin samples of the seven cultivars were then analysed further.

\section{Determination of $\mathrm{pH}$, total soluble solids and ascorbic acid}

The $\mathrm{pH}$ was measured using a digital $\mathrm{pH}$ meter (Sartorius, PP-50) at $21^{\circ} \mathrm{C}$. The total soluble solids (TSS) were determined with a digital refractometer (Bury Road-REF-107, calibrated using distilled water) and the results were reported as ${ }^{\circ} \mathrm{Brix}$ at $30^{\circ} \mathrm{C}$. The ascorbic acid (AA) concentration was determined according to the method described by Ruck (1963) and the results were expressed as $\mathrm{mg} / 100 \mathrm{~g}$ of juice.

\section{Total flavonoid content (TFC)}

Total flavonoid content (TFC) Lin and Tang's (2007) method was applied for determing TFC. Quercetin and distilled water were used as standard and blank, 
respectively. The final reaction mixture consisted of $0.2 \mathrm{~mL}$ of the sample, $1.5 \mathrm{~mL}$ of ethanol solution (95\%), $0.1 \mathrm{~mL}$ of aluminium chloride $(10 \%)$ and potassium acetate $(1 \mathrm{~mol} / \mathrm{L})$, and $2.8 \mathrm{~mL}$ of distilled water. The absorbance was read at $415 \mathrm{~nm}$ after $30 \mathrm{~min}$ of reaction. The results were reported as $\mathrm{mg} \mathrm{QuE}$ (quercetin equivalent)/L of pomegranate juice or skin and each sample was measured in triplicate.

\section{Total anthocyanin content (TAC)}

Total anthocyanin content was measured by the $\mathrm{pH}$ differential method (Giusti and Wrolstad, 2001). $0.5 \mathrm{~mL}$ of each sample was brought to $\mathrm{pH} 1.0$ by adding $4.5 \mathrm{~mL}$ of $\mathrm{KCl}-\mathrm{HCl}$ solution $(0.025 \mathrm{~mol} / \mathrm{L})$ and to $\mathrm{pH} 4.5$ by $4.5 \mathrm{~mL}$ of $\mathrm{NaOAc}-\mathrm{HOAc}$ solution $(0.4 \mathrm{~mol} / \mathrm{L})$, respectively. The absorbance of equilibrated reaction mixture solutions $\left(\sim 25^{\circ} \mathrm{C}, 15 \mathrm{~min}\right.$ standing) was measured at $510 \mathrm{~nm}$ and at $700 \mathrm{~nm}$, respectively, using a UV-VIS spectrophotometer (JENWAY, 6300) at ambient temperature with distilled water as blank. The results were expressed as mg CyE (cyanidin-3-glucoside equivalent)/L juice or skin. Each sample was tested in triplicate.

\section{Total tannin content (TTC)}

Total tannin content was tested according to the previously reported method (Schanderl, 1970) with some modifications. Tannic acid was used as the standard and distilled water as the blank. Folin-Dennis reagent was prepared by refluxing the mixture of sodium tungstate dihydrate $(100 \mathrm{~g})$, phosphomolybdic acid $(20 \mathrm{~g}), \mathrm{H}_{2} \mathrm{O}(750 \mathrm{~mL})$ with phosphoric acid $(50 \mathrm{~mL})$ in a water bath for 2 hours, then diluted to $1000 \mathrm{~mL}$ after cooling. The final reaction mixture contained $1.0 \mathrm{~mL}$ of the diluted sample $(2 \mathrm{~mL}$ of each sample was diluted into $10 \mathrm{~mL}$ using distilled water), $1.25 \mathrm{~mL}$ Folin-Dennis reagent and $2.5 \mathrm{~mL}$ sodium carbonate solution $(10 \%)$. The mixture was brought to a volume of $25 \mathrm{~mL}$ using distilled water. The absorbance of the mixture was read at $700 \mathrm{~nm}$ after 30 mins' reaction in the dark. The results were expressed as $\mathrm{mg} \mathrm{TaE} \mathrm{(tannic}$ acid equivalent $) / L$ of pomegranate juice or skin. Each sample was measured in triplicate.

\section{Total phenolic content (TPC)}

Total phenolic content was measured by the Folin-Ciocalteu method, based on the optimized conditions established by Singleton et al. (1999). Gallic acid and distilled water were used as standard and blank, respectively. $0.5 \mathrm{~mL}$ of diluted juice $(2 \mathrm{~mL}$ juice sample was diluted into $10 \mathrm{~mL}$ of distilled water) were mixed with $0.5 \mathrm{~mL}$ of Folin-Ciocalteu reagent before adding $3 \mathrm{~mL}$ of sodium carbonate solution $(10 \%)$. Water was added to reach a volume of $10 \mathrm{~mL}$. The absorbance was read at $760 \mathrm{~nm}$ after 30 mins' reaction in the dark. The results were recorded as mg GaE (gallic acid equivalent $/ \mathrm{L}$ of pomegranate juice or skin. Each sample was tested in triplicate.

\section{Total antioxidant activity (TAA)}

The TAA of each sample was determined by adapting the method used by Govindarajan et al. (2003) and Subhasree et al. (2009) with slight modifications. In brief, the sample was diluted with distilled water $(60-220 \mathrm{mg} / \mathrm{mL})$. The diluted sample $(0.2 \mathrm{~mL})$ was then mixed with $1.8 \mathrm{~mL}$ of reagent $(0.6 \mathrm{M}$ sulphuric acid, $28 \mathrm{mM}$ sodium phosphate and $4 \mathrm{mM}$ ammonium molybdate) in a capped plastic tube. The tube was incubated in a water bath at $90^{\circ} \mathrm{C}$ for $90 \mathrm{~min}$, then cooled down to room temperature. The absorbance of this solution was measured at $695 \mathrm{~nm}$ using a UV-VIS spectrophotometer against a blank. Ascorbic acid $\left(5-60 \times 10^{3} \mathrm{mg} / \mathrm{L}\right)$ was used as standard. TAA was expressed as $\mathrm{mg}$ Ascorbic acid equivalent/L of pomegranate juice or skin.

\section{Statistical analysis}

Analysis of variance (ANOVA) was carried out using SAS software and significant differences among the means were determined at $P<0.05$ using LSD test.

\section{RESULTS AND DISCUSSION}

\section{Physical characteristics}

The physical characteristics of the pomegranate cultivars are shown in Table 1. The juice content of the whole fruits varied from $72.9 \pm 2.55 \%$ (ZZ) to $26.7 \pm 0.98 \%$ (B) (Table 1). In the study by Zarei et al. (2010), the juice content of 'Rabab-e-Fars' was $48.02 \pm 1.02 \%$. Moreover, the juice content of ' $\mathrm{MS}$ ' and 'MY' was $72.09 \pm 13.46 \%$ and $85.00 \pm 9.54 \%$, respectively (Tehranifar et al., 2010a). According to our knowledge, the physico-chemical properties of the other selected pomegranate cultivars have not been previously reported in the literature. 
Table 1. Fresh fruit weight (FFW), dried fruit weight (DFW), juice percentage (JP), juice density (JD), total soluble solid (TSS) and $\mathrm{pH}$ of seven selected pomegranate cultivars

\begin{tabular}{lcccccc}
\hline Cultivars & FFW, & DFW, & JP, $\%$ & JD, $/ \mathrm{mL}$ & \multicolumn{1}{c}{ TSS, ${ }^{\circ}$ Brix } & $\mathrm{pH}$ \\
\hline RPS & $170.1 \pm 5.67 \mathrm{~cd}$ & $110.3 \pm 4.66 \mathrm{~b}$ & $35.2 \pm 1.43 \mathrm{c}$ & $0.975 \pm 0.05 \mathrm{a}$ & $16.78 \pm 1.56 \mathrm{c}$ & $3.7 \pm 0.1 \mathrm{c}$ \\
RPGH & $210.3 \pm 7.03 \mathrm{a}$ & $125.9 \pm 3.48 \mathrm{a}$ & $40.1 \pm 1.08 \mathrm{~b}$ & $0.94 \pm 0.07 \mathrm{a}$ & $16.78 \pm 1.04 \mathrm{c}$ & $3.19 \pm 0.04 \mathrm{e}$ \\
ZZ & $175 \pm 4.87 \mathrm{c}$ & $27.5 \pm 1.01 \mathrm{~d}$ & $72.9 \pm 2.55 \mathrm{a}$ & $0.938 \pm 0.05 \mathrm{a}$ & $17.78 \pm 1.21 \mathrm{~b}$ & $3.82 \pm 0.09 \mathrm{~b}$ \\
SZ & $161.2 \pm 3.74 \mathrm{~d}$ & $43.9 \pm 1.12 \mathrm{~d}$ & $72.8 \pm 1.8 \mathrm{a}$ & $0.96 \pm 0.08 \mathrm{a}$ & $14.78 \pm 1.76 \mathrm{e}$ & $4.02 \pm 0.12 \mathrm{a}$ \\
MY & $130.9 \pm 8.14 \mathrm{f}$ & $95.1 \pm 2.22 \mathrm{c}$ & $27.6 \pm 1.22 \mathrm{~d}$ & $0.942 \pm 0.05 \mathrm{a}$ & $15.78 \pm 0.87 \mathrm{~d}$ & $3.74 \pm 0.11 \mathrm{bc}$ \\
MS & $189.4 \pm 5.32 \mathrm{~b}$ & $112.3 \pm 4.43 \mathrm{~b}$ & $40.4 \pm 0.48 \mathrm{~b}$ & $0.86 \pm 0.08 \mathrm{~b}$ & $17.78 \pm 2.1 \mathrm{~b}$ & $3.55 \pm 0.05 \mathrm{~d}$ \\
B & $149.7 \pm 2.56 \mathrm{e}$ & $108.7 \pm 4.55 \mathrm{~b}$ & $26.7 \pm 0.98 \mathrm{~d}$ & $0.93 \pm 0.45 \mathrm{a}$ & $18.79 \pm 1.06 \mathrm{a}$ & $2.84 \pm 0.08 \mathrm{f}$ \\
\hline
\end{tabular}

Means \pm standard deviation $(n=10)$ in each column followed by different letters are significantly different $(P<0.05)$.

RPS - 'Rabab-e-Pust Sefid', RPGH - 'Rabab-e-Pust Ghermez', ZZ - 'Zagh-e-Zabol', SZ - 'Siah-e-Zabol', MY - 'Malas-e-Yazd', MS - 'Malas-e-Saveh', B - 'Bajestan'.

\section{Total soluble solids (TSS) and pH}

The results for $\mathrm{pH}$ and TSS of the skins and juices from different pomegranate cultivars are reported in Table 1. Significant differences $(P<0.05)$ were revealed among the pomegranate cultivars for TSS and $\mathrm{pH}$. The highest and lowest TSS content were measured in 'B' $\left(18.79^{\circ}\right.$ Brix) and 'SZ' $\left(14.78^{\circ}\right.$ Brix $)$, respectively.

In previous studies on cultivars grown in Iran, the TSS values were $13.37 \pm 0.46^{\circ}$ Brix and $14.02 \pm 0.74^{\circ}$ Brix for 'MS' and 'MY' (Tehranifar et al., 2010a), respectively, and $13.2^{\circ}$ Brix for 'Pust-e-Siah' (Tehranifar et al., 2010b). The $\mathrm{pH}$ values ranged between $4.02 \pm 0.12$ (SZ) and $2.84 \pm 0.08$ (B) (Table 1). Cultivar 'B' showed the lowest $\mathrm{pH}$, which is in accordance with the highest ascorbic acid content in this cultivar. In previous studies, $\mathrm{pH}$ was measured in 'Rabab-e-Fars' $(3.23 \pm 0.020)$ (Zarei et al., 2010), 'MS' and 'MY' (3.43 \pm 0.07 and $3.52 \pm 0.12$, respectively) (Tehranifar et al., 2010a), and 'Pust-e-Siah' (3.85) (Tehranifar et al., 2010b).

\section{Ascorbic acid (AA) concentration}

It is worth noting that the AA concentration was higher in the skins than the juices. The highest content of AA was determined in the skin of ' $\mathrm{B}$ ' $(16.54 \pm 2.09$ $\mathrm{mg} / 100 \mathrm{~g}$ ) (Table 2).

The AA concentration has been also investigated in some cultivars grown in Iran, namely 'Rabab-e-Fars' (9.78 $\pm 0.44 \mathrm{mg} / 100 \mathrm{~g}$; Zarei et al., 2010), 'MS' and 'MY' $(9.91 \pm 0.84$ and $20.92 \pm 2.00 \mathrm{mg} / 100 \mathrm{~g}$, respectively; Tehranifar et al., 2010a) and 'Pust-e-Siah' (15.1 mg/100 g; Tehranifar et al., 2010b).

\section{Total flavonoid content (TFC)}

Total flavonoid content was higher in the skins than in the juices. The highest TFC was measured in the skin of 'SZ' $(930 \pm 16 \mathrm{mg} \mathrm{QuE} / \mathrm{L})$ and the lowest in the juice of 'MS' (14.3 $\pm 4.8 \mathrm{mg}$ QuE/L) (Table 2). Total flavonoid content measurement of ten Chinese pomegranate cultivars revealed $0.045-0.335 \mathrm{mg} \mathrm{QuE} / \mathrm{mL}$ (Li et al., 2015).

\section{Total anthocyanin content (TAC)}

The highest and the lowest TAC were observed in the skins of 'B' $(11.20 \pm 2.4 \mathrm{mg} \mathrm{CyE} / \mathrm{L})$ and 'MY' $(0.05$ $\pm 0.02 \mathrm{mg} \mathrm{CyE} / \mathrm{L}$ ), respectively (Table 2 ).

Total anthocyanin content was previously measured in some Iranian pomegranate cultivars: 'Rabab-e-Fars' $(24.43 \pm 0.41 \mathrm{mg} / 100 \mathrm{~g}$ ) (Zarei et al., 2010), 'MS' and 'MY' $(6.90 \pm 0.23$ and $30.11 \pm 3.63 \mathrm{mg} / 100 \mathrm{~g}$, respectively) (Tehranifar et al., 2010a) and 'Pust-e-Siah' $(26.9 \mathrm{mg} / 100 \mathrm{~g})$ (Tehranifar et al., 2010b). Furthermore, the TAC of ten Chinese cultivars (0.004-0.160 $\mathrm{mg} \mathrm{CyE} / \mathrm{mL}$ ) was also reported (Li et al., 2015).

\section{Total tannin content (TTC)}

The juices of the pomegranate cultivars exhibited a higher TTC than the skins. The values ranged from $1.09 \pm 0.07 \mathrm{mg} \mathrm{TaE} / \mathrm{L}$ (in skin of ' $Z Z$ ') to $6.55 \pm 0.5 \mathrm{mg}$ 
Mottaghipisheh, J., Ayanmanesh, M., Babadayei-Samani, R., Javid, A., Sanaeifard, M., Vitalini, S., Iriti, M. (2018). Total anthocyanin, flavonoid, polyphenol and tannin contents of seven pomegranate cultivars grown in Iran. Acta Sci. Pol. Technol. Aliment., 17(3), 211-217. http://dx.doi.org/10.17306/J.AFS.2018.0584

Table 2. Total flavonoid (TFC), anthocyanin (TAC), tannin (TTC), polyphenol (TPC) contents, antioxidant activity (TAA) and ascorbic acid content (AA) of juice (J) and skin (S) of seven Iranian pomegranate cultivars

\begin{tabular}{|c|c|c|c|c|c|c|c|c|c|c|c|c|}
\hline \multirow{2}{*}{ Cultivars } & \multicolumn{2}{|c|}{$\mathrm{TFC}, \mathrm{mg} / \mathrm{L}$} & \multicolumn{2}{|c|}{$\mathrm{TAC}, \mathrm{mg} / \mathrm{L}$} & \multicolumn{2}{|c|}{ TTC, mg/L } & \multicolumn{2}{|c|}{$\mathrm{TPC}, \mathrm{mg} / \mathrm{L}$} & \multicolumn{2}{|c|}{ TAA, mg/L } & \multicolumn{2}{|c|}{$\mathrm{AA}, \mathrm{mg} / 100 \mathrm{~g}$} \\
\hline & $\mathrm{J}$ & $\mathrm{S}$ & $\mathrm{J}$ & $S$ & $\mathrm{~J}$ & $\mathrm{~S}$ & $\mathrm{~J}$ & $\mathrm{C}$ & $\mathrm{J}$ & $S$ & $\mathrm{~J}$ & S \\
\hline $\mathrm{R}$ & & & $\begin{array}{c}0.87 \\
\pm 0.1 \mathrm{c}\end{array}$ & & $\begin{array}{c}3.05 \\
\pm 0.34 \mathrm{bc}\end{array}$ & $\begin{array}{r}3 \\
\pm 0 .\end{array}$ & $\begin{array}{c}1018 \\
\pm 22.1 \mathrm{~b}\end{array}$ & $\begin{array}{c}785 \\
\pm 11.1 \mathrm{a}\end{array}$ & $\begin{array}{c}4 \\
\pm 4\end{array}$ & $\begin{array}{c}47 \\
\pm 10.1 \mathrm{~d}\end{array}$ & $\begin{array}{r}4 . \\
\pm 1\end{array}$ & $\begin{array}{r}12.56 \\
\pm 2.1 \mathrm{ab}\end{array}$ \\
\hline RPC & $\begin{array}{c}259.6 \\
\pm 9 \mathrm{~d}\end{array}$ & $\begin{array}{c}328.2 \\
\pm 13.9 \mathrm{~g}\end{array}$ & $\begin{array}{c}0.18 \\
\pm 0.04 \mathrm{e}\end{array}$ & $\begin{array}{c}0.26 \\
\pm 0.03 \mathrm{~d}\end{array}$ & $\begin{array}{r}2.2 \\
\pm 0.9\end{array}$ & $\begin{array}{l}4.46 \\
\pm 1 \mathrm{a}\end{array}$ & $\begin{array}{c}1082 \\
\pm 12.8 \mathrm{a}\end{array}$ & $\begin{array}{c}645 \\
\pm 31.1 \mathrm{~d}\end{array}$ & $\begin{array}{l}3 \\
\pm 2\end{array}$ & $\begin{array}{c}133 \\
\pm 8.7 \mathrm{~b}\end{array}$ & $\begin{array}{c}4.65 \\
\pm 1.9 \mathrm{~b}\end{array}$ & 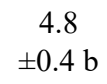 \\
\hline $\mathrm{ZZ}$ & $\begin{array}{c}282.1 \\
\pm 11.0 \mathrm{c}\end{array}$ & $\begin{array}{c}587.2 \\
\pm 10.2 \mathrm{~d}\end{array}$ & $\begin{array}{c}0.44 \\
\pm 0.1 \mathrm{~d}\end{array}$ & $\begin{array}{c}1.57 \\
\pm 0.5 \mathrm{c}\end{array}$ & $\begin{array}{c}6.33 \\
\pm 0.1 \mathrm{a}\end{array}$ & $\begin{array}{c}1.09 \\
\pm 0.7 \mathrm{c}\end{array}$ & $\begin{array}{c}960 \\
\pm 17.5 \mathrm{c}\end{array}$ & $\begin{array}{c}671 \\
\pm 20.02 \mathrm{c}\end{array}$ & $\begin{array}{c}8311 \\
\pm 56.1 \mathrm{bc}\end{array}$ & $\begin{array}{c}70 \\
\pm 12.2 \mathrm{c}\end{array}$ & $\begin{array}{c}4.87 \\
\pm 0.5 \mathrm{~b}\end{array}$ & $\begin{aligned} & 8.05 \\
\pm & 2.2 \mathrm{ab}\end{aligned}$ \\
\hline SZ & $\begin{array}{r}342 \\
\pm 12.1 \mathrm{a}\end{array}$ & $\begin{array}{c}930 \\
\pm 16 \mathrm{a}\end{array}$ & $\begin{array}{c}8.22 \\
\pm 1.9 \mathrm{a}\end{array}$ & $\begin{array}{c}1.69 \\
\pm 0.6 \mathrm{c}\end{array}$ & $\begin{array}{c}4.12 \\
\pm 0.8 \mathrm{ab}\end{array}$ & $\begin{array}{c}2.43 \\
\pm 1 \mathrm{bc}\end{array}$ & $\begin{array}{c}1026 \\
\pm 21.3 \mathrm{~b}\end{array}$ & $\begin{array}{c}705 \\
\pm 23.3 \mathrm{~b}\end{array}$ & $\begin{array}{c}9193 \\
\pm 78.2 \mathrm{~b}\end{array}$ & $\begin{array}{c}69 \\
\pm 9.3 \mathrm{c}\end{array}$ & $\begin{array}{c}4.45 \\
\pm 2.1 \mathrm{~b}\end{array}$ & $\begin{aligned} & 8.12 \\
\pm & 1.4 \mathrm{ab}\end{aligned}$ \\
\hline MY & $\begin{array}{c}320.6 \\
\pm 9.9 \mathrm{~b}\end{array}$ & $\begin{array}{c}502.4 \\
\pm 9.1 \mathrm{e}\end{array}$ & $\begin{array}{c}0.63 \\
\pm 0.2 \mathrm{~d}\end{array}$ & $\begin{array}{c}0.05 \\
\pm 0.02 \mathrm{~d}\end{array}$ & $\begin{array}{c}5.21 \\
\pm 1.1 \mathrm{a}\end{array}$ & $\begin{array}{c}4.43 \\
\pm 2.4 \mathrm{a}\end{array}$ & $\begin{array}{c}706 \\
\pm 23.9 \mathrm{e}\end{array}$ & $\begin{array}{c}553 \\
\pm 12.5 \mathrm{f}\end{array}$ & $\begin{array}{c}17715 \\
\pm 42.1 \mathrm{a}\end{array}$ & $\begin{array}{c}308 \\
\pm 21.1 \mathrm{a}\end{array}$ & $\begin{aligned} & 4.6 \\
\pm & 1.2 \mathrm{~b}\end{aligned}$ & $\begin{array}{c}4.02 \\
\pm 0.7 \mathrm{~b}\end{array}$ \\
\hline MS & $\begin{array}{c}14.3 \\
\pm 4.8 \mathrm{f}\end{array}$ & $\begin{array}{c}382.1 \\
\pm 17.5 \mathrm{f}\end{array}$ & $\begin{array}{c}0.48 \\
\pm 0.1 \mathrm{~d}\end{array}$ & $\begin{array}{c}0.16 \\
\pm 0.01 \mathrm{~d}\end{array}$ & $\begin{array}{c}6.55 \\
\pm 0.5 \mathrm{a}\end{array}$ & $\begin{array}{c}4.22 \\
\pm 2.2 \mathrm{a}\end{array}$ & $\begin{array}{c}1062 \\
\pm 14.1 \mathrm{a}\end{array}$ & $\begin{array}{c}597 \\
\pm 18.8 \mathrm{e}\end{array}$ & $\begin{array}{c}7009 \\
\pm 23.8 \mathrm{c}\end{array}$ & $\begin{array}{c}137 \\
\pm 15.2 \mathrm{~b}\end{array}$ & $\begin{aligned} & 4.1 \\
\pm & 1.3 \mathrm{~b}\end{aligned}$ & $\begin{array}{c}4.21 \\
\pm .05 \mathrm{~b}\end{array}$ \\
\hline B & $\begin{array}{c}100 \\
\pm 10.1 \mathrm{e}\end{array}$ & $\begin{array}{l}712.7 \\
\pm 9 \mathrm{c}\end{array}$ & $\begin{array}{c}1.13 \\
\pm 0.2 \mathrm{~b}\end{array}$ & $\begin{array}{l}11.20 \\
\pm 2.4 \mathrm{a}\end{array}$ & $\begin{array}{c}1.01 \\
\pm 0.4 \mathrm{~d}\end{array}$ & $\begin{array}{c}4.1 \\
\pm 0.8 \mathrm{a}\end{array}$ & $\begin{array}{c}896 \\
\pm 12.1 \mathrm{~d}\end{array}$ & $\begin{array}{c}783 \\
\pm 10.02 \mathrm{a}\end{array}$ & $\begin{array}{r}8325 \\
\pm 32.1 \mathrm{bc}\end{array}$ & $\begin{array}{c}28 \\
\pm 3.1 \mathrm{e}\end{array}$ & $\begin{array}{c}8.76 \\
\pm 1.8 \mathrm{a}\end{array}$ & $\begin{array}{c}16.54 \\
\pm 2.1 \mathrm{a}\end{array}$ \\
\hline
\end{tabular}

Data were expressed as mean \pm standard deviation $(n=3)$. Different letters represent significant differences $(P<0.05)$.

RPS - 'Rabab-e-Pust Sefid', RPGH - 'Rabab-e-Pust Ghermez', ZZ - 'Zagh-e-Zabol', SZ - 'Siah-e-Zabol', MY - 'Malas-e-Yazd', MS - 'Malas-e-Saveh', B - 'Bajestan'.

$\mathrm{TaE} / \mathrm{L}$ (in juice 'MS') (Table 2). In an earlier study, TTC was $32.60 \pm 0.240 \mathrm{mg} \mathrm{Ta} / 100 \mathrm{~g}$ in 'Rabab-e-Fars' (Zarei et al., 2010), and $0.540-2.531 \mathrm{mg} \mathrm{TaE} / \mathrm{mL}$ in Chinese cultivars (Li et al., 2015).

\section{Total phenolic content (TPC)}

Total phenolic content was higher in the juices than the skins. The juice of 'RPGH' exhibited the highest TPC $(1082 \pm 12.8 \mathrm{mg} \mathrm{GaE} / \mathrm{L})$, while the lowest was measured in the skin of 'MY' $(553 \pm 12.5 \mathrm{mg} \mathrm{GaE} / \mathrm{L})$ (Table 2). Tehranifar et al. (2010a) investigated the TPC of 'MS' and 'MY' (710.74 \pm 11.68 and 916.03 $\pm 22.11 \mathrm{mg} / 100 \mathrm{~g}$, respectively), and 'Pust-e-Siah' $(984.2 \mathrm{mg} / 100 \mathrm{~g})$ (Tehranifar et al., 2010b). The TPC of some Chinese cultivars was also determined and reached 3.15-7.43 mg GaE/mL (Li et al., 2015).

\section{Total antioxidant activity (TAA)}

Total antioxidant activity was much higher in the juices than the skins. As shown in Table 2, TAA ranged from 17,715 $\pm 42.08 \mathrm{mg} / \mathrm{L}$ (in juice of 'MY') to $28 \pm 3.12 \mathrm{mg} / \mathrm{L}$ (in skin of 'B'). Total antioxidant activity of 'Rabab-e-Fars' (51.44 \pm 1.49 percentage of inhibition) (Zarei et al., 2010), 'MS' and 'MY' (29.87 $\pm 1.77 \%$ and $35.60 \pm 1.37 \%$, respectively) (Tehranifar et al., 2010a) and 'Pust-e-Siah' (54.4\%) (Tehranifar et al., 2010b) have been previously reported.

As expected, total antioxidant activity exhibited a direct correlation with total polyphenol content (Fig. 1), in agreement with a very recent report (Dżugan et al., 2018). A number of health benefits have been attributed to pomegranates, particularly in the prevention of cardiovascular disease, neurodegenerative disorders and certain types of cancer. In turn, these health-promoting effects have been ascribed to powerful antioxidant activity (Sing et al., 2018). Certainly, these properties rely on the variety of bioactive phytochemicals present in pomegranate products exerting possible additive/synergistic effects on multiple molecular and biochemical targets involved in the main chronic degenerative diseases. 

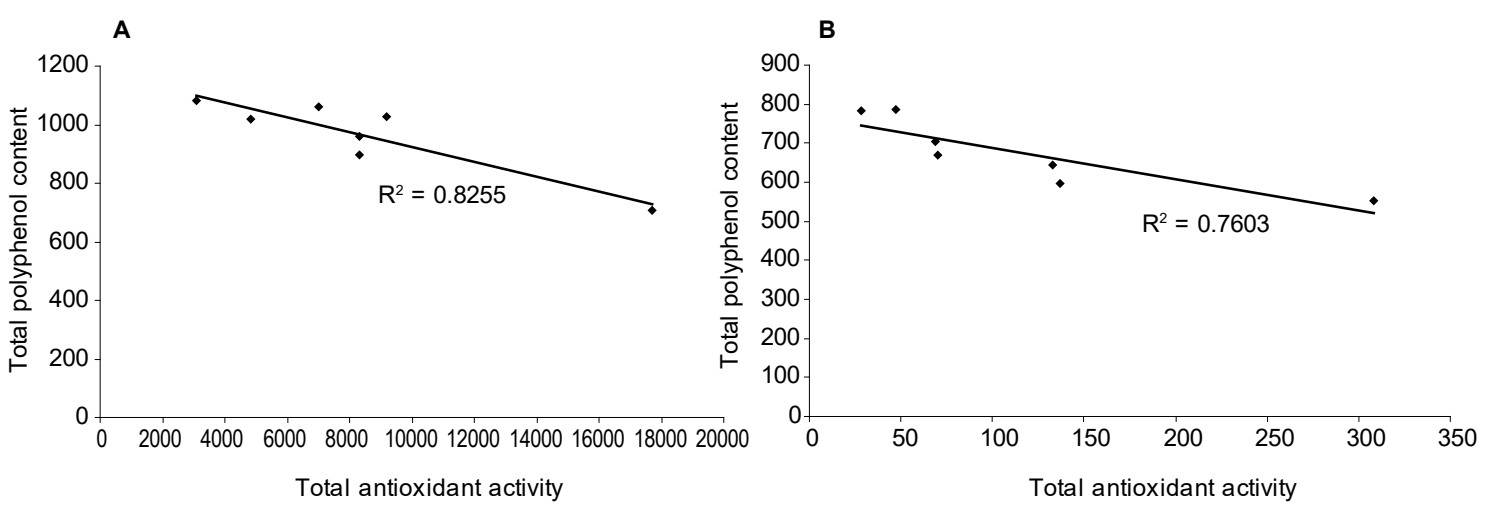

Fig. 1. Correlation analysis based on simple linear regression at the $95 \%$ confidence level between total antioxidant activity and total polyphenol content in pomegranate (A) juices and (B) skins

\section{CONCLUSIONS}

Pomegranate juices and skins from seven representative Iranian cultivars showed different physico-chemical characteristics and polyphenol contents. To the best of our knowledge, the skins and juices of these cultivars were investigated for the first time. The juice of pomegranate cultivars, particularly 'Malas-e-Yazd', can be used as a powerful antioxidant agent in food and pharmaceutical industries. Moreover, the skin of 'Siah-e-Zabol' deserves particularly attention. However, further phytochemical analyses are needed to identify the most representative phenylpropanoids by LC-MS and to develop novel and promising dietary supplements.

\section{ACKNOWLEDGMENT}

This study was financially supported by Islamic Azad University, Estahban Branch, Iran. The authors thank Fars Agricultural \& Natural Resources Research and Education Centre for its experimental work.

\section{REFERENCES}

Ambigaipalan, P., de Camargo, A. C., Shahidi, F. (2017). Identification of phenolic antioxidants and bioactives of pomegranate seeds following juice extraction using HPLC-DAD-ESI-MSn. Food Chem., 221, 1883-1894. https://doi.org/10.1016/j.foodchem.2016.10.058

Aviram, M., Dornfeld, L., Rosenblat, M., Volkova, N., Kaplan, M., Coleman, ..., Fuhrman, B. (2000). Pomegranate juice consumption reduces oxidative stress and low density lipoprotein atherogenic modifications: studies in the atherosclerotic apolipoprotein $\mathrm{E}$ deficient mice and in humans. Am. J. Clin. Nutr., 71(5), 1062-1076. https:// doi.org/10.1016/S0021-9150(00)80502-X

Behzadi Shahrbabaki, H. (1998). Genetic diversity of pomegranate genotypes in Iran. Nashr Amoozesh Keshavarzi.

Dżugan, M., Wesołowska, M., Zaguła, G., Puchalski, C. (2018). The comparison of the physicochemical parameters and antioxidant activity of homemade and commercial pomegranate juices. Acta Sci. Pol. Technol. Aliment., 17(1), 56-68. http://dx.doi.org/10.17306/J. AFS.0529

Giusti, M. M., Wrolstad, R. E. (2001). Characterization and measurement of anthocyanins by UV-visible spectroscopy. Curr. Protoc. Food Anal. Chem. (pp. 1-13). New York: John Wiley and Sons.

Govindarajan, R., Rastogi, S., Vijayakumar, M., Shirwaikar, A., Singh Rawat, A. K., Mehrotra, S., Pushpangadan, P. (2003). Studies on the antioxidant activities of Desmodium gangeticum. Biol. Pharm. Bull., 26(10), 1424-1427.

Harlan, J. (1992). Crops and man (2nd ed., pp. 289). Madison, WI: American Society of Agronomy and Crop Science Society of America.

Hmid, I., Elothmani, D., Hanine, H., Oukabli, A., Mehinagic, E. (2017). Comparative study of phenolic compounds and their antioxidant attributes of eighteen pomegranate (Punica granatum L.) cultivars grown in Morocco. Arab. J. Chem., 10, S2675-S2684. https://doi. org/10.1016/j.arabjc.2013.10.011

Hmid, I., Hanine, H., Elothmani, D., Oukabli, A. (2016). The physico-chemical characteristics of Morrocan 
pomegranate and evaluation of the antioxidant activity for their juices. J. Saudi Soc. Agric. Sci. https://doi. org/10.1016/j.jssas.2016.06.002

Levin, G. M. (1994). Pomegranate (Punica granatum L.) plant genetic resources in Turkmenistan. Plant. Gene. Res. Newslet., 97, 31-36.

Li, X., Wasila, H., Liu, L., Yuan, T., Gao, Z., Zhao, B., Ahmad, I. (2015). Physicochemical characteristics, polyphenol compositions and antioxidant potential of pomegranate juices from 10 Chinese cultivars and the environmental factors analysis. Food Chem., 175, 575584. https://doi.org/10.1016/j.foodchem.2014.12.003

Lin, J., Tang, C. (2007). Food chemistry determination of total phenolic and flavonoid contents in selected fruits and vegetables, as well as their stimulatory effects on mouse splenocyte proliferation. Food Chem., 101, 140 147. https://doi.org/10.1016/j.foodchem.2006.01.014

Melgarejo, P., Salazar, D. M., Artes, F. (2000). Organic acids and sugars composition of harvested pomegranate fruits. Eur. Food Res. Technol., 211, 185-190. https:// doi.org/10.1007/s002170050021

Mphahlele, R. R., Fawole, O. A., Mokwena, L. M., Opara, U. L. (2016). Effect of extraction method on chemical, volatile composition and antioxidant properties of pomegranate juice. South Afr. J. Bot., 103, 135-144. https://doi.org/10.1016/j.sajb.2015.09.015

Ozgen, M., Durgaç, C., Serçe, S., Kaya, C. (2008). Chemical and antioxidant properties of pomegranate cultivars grown in the Mediterranean region of Turkey. Food Chem., 111(3), 703-706. https://doi.org/10.1016/ j.foodchem.2008.04.043

Özkan, M. (2002). Degradation of anthocyanins in sour cherry and pomegranate juices by hydrogen peroxide in the presence of added ascorbic acid. Food Chem., 78(4), 499-504. https://doi.org/10.1016/S0308-8146(02) 00165-6

Ruck, J. (1963). Chemical methods for analysis of fruits and vegetable products. Canada Deptt. Agri. Publication, 1154.

Sarkhosh, A., Zamani, Z., Fatahi, R., Ebadi, A. (2006). RAPD markers reveal polymorphism among some Iranian pomegranate (Punica granatum L.) genotypes. Sci. Hortic. (Amsterdam), 111(1), 24-29. https://doi. org/10.1016/j.scienta.2006.07.033

Schanderl, S. H. (1970). Tannins and related phenolics. In: M. A. Joslin (Ed.), Methods in food analysis (pp. 701724). New York: Academic Press.
Singh, B., Singh, J. P., Kaur, A., Singh, N. (2018). Phenolic compounds as beneficial phytochemicals in pomegranate (Punica granatum L.) peel: A review. Food Chem., 261, 75-86.

Singleton, V. L., Orthofer, R., Lamuela-Raventos, R. M. (1999). Analysis of total phenols and other oxidation substrates and antioxidants by means of Folin-Ciocalteu Reagent. Methods Enzymol., 299, 152-178.

Stover, E., Mercure, E. W. (2007). The pomegranate: A new look at the fruit of paradise. HortScience, 42(5), 1088-1092.

Subhasree, B., Baskar, R., Keerthana, R. L., Susan, R. L., Rajasekaran, P. (2009). Evaluation of antioxidant potential in selected green leafy vegetables. Food Chem., 115(4), 1213-1220. https://doi.org/10.1016/j. foodchem.2009.01.029

Tehranifar, A., Zarei, M., Nemati, Z., Esfandiyari, B., Vazifeshenas, M. R. (2010a). Investigation of physicochemical properties and antioxidant activity of twenty Iranian pomegranate (Punica granatum L.) cultivars. Sci. Hortic. (Amsterdam), 126(2), 180-185. https://doi. org/10.1016/j.scienta.2010.07.001

Tehranifar, A., Zarei, M., Esfandiyari, B., Nemati, Z. (2010b). Physicochemical properties and antioxidant activities of pomegranate fruit (Punica granatum) of different cultivars grown in Iran. Hort. Environ. Biotechnol., 51(6), 573-579.

Turgut, S. S., Işıkçı, F., Soyer, A. (2017). Antioxidant activity of pomegranate peel extract on lipid and protein oxidation in beef meatballs during frozen storage. Meat Sci., 129, 111-119. https://doi.org/10.1016/j. meatsci.2017.02.019

Verma, N., Mohanty, A., Lal, A. (2010). Pomegranate genetic resources and germplasm conservation: A review. Fruit Veg. Cereal Sci. Biotechnol., 4(2), 120-125.

Zaouay, F., Mena, P., Garcia-Viguera, C., Mars, M. (2012). Antioxidant activity and physico-chemical properties of Tunisian grown pomegranate (Punica granatum L.) cultivars. Ind. Crops Prod., 40(1), 81-89. https://doi. org/10.1016/j.indcrop.2012.02.045

Zarei, M., Azizi, M., Bashiri-Sadr, Z. (2010). Studies on physico-chemical properties and bioactive compounds of six pomegranate cultivars grown in Iran. J. Food Technol., 8(3), 112-117. https://doi.org/10.3923/ jftech.2010.112.117 